\title{
POST-MILLENNIAL VISEGRÁD FOUR GEOPOLITICS: ILLIBERALISM AND POSITIONALITY WITHIN THE EU
}

\author{
James Wesley SCOTT
}

${ }^{a}$ Karelian Institute, University of Eastern Finland, 80100 Joensuu, Yliopistokatu 2. Finland James.scott@uef.fi

Cite this article: Scott, J. W. (2021). Post-Millennial Visegrád Four Geopolitics: Illiberalism and Positionality within the EU. Deturope, 13(2): 13-33.

\begin{abstract}
This research paper analyses shifts in the Visegrád Group's (Czechia, Hungary, Poland and Slovakia) identity as a regional integration platform and, in particular, links between Europeanization, illiberalism and V4 geopolitical identity. This provides a background for investigating contested ideas of European integration that discursively frame Central Europe's 'illiberal regionalism'. I suggest that this regionalism does not represent a coherent or stable political project. Tensions involved in this regionalist shift are exemplified by 'revolutionary' Hungarian and Polish national conservative agendas and their interaction with the more measured pragmatism of the Czech Republic and Slovakia. This analysis supports the argument that V4 cooperation represents an adjustable geopolitical space that reflects Hungarian and Polish cultural politics of national identity as well as more issue-oriented Czech and Slovak concerns. Moreover, V4 cooperation remains salient in order to prevent the political marginalization of its members.
\end{abstract}

Keywords: Europeanization, Visegrád Four, Central Europe, Critical Geopolitics, Illiberal Democracy

\section{INTRODUCTION}

The Visegrád Group (comprised of the Czech Republic, Hungary, Poland and Slovakia) represents an important platform for subregional cooperation within the European Union. This relationship between the 'V4' and the EU formally began in 1991 as part of the 'return to Europe' proclaimed by Vaclav Havel and was celebrated as a historical break with State Socialism and Cold War divisions. However, by 2016 western European media were characterizing the Visegrád 4 (henceforth V4) as an 'awkward quartet' (Buckley \& Foy, 2016), a loose association of post-socialist EU members bent on overturning the European Union's institutions. Indeed, the vehement nature of anti-refugee political sentiment in V4 countries has been interpreted as a shift in the group's geopolitical identity. This shift has been characterised as a partial abandonment of Europeanization and, in the most negative readings, as a project of fragmentation and contestation of the European project itself (see Nič, 2016). Aliaksei Kazharski (2018) has therefore posed the provocative question whether the V4's increasing 
lack of normative conformity with the European Union mainstream signifies an 'end' to the idea of Central Europe or whether Central Europe itself is in the process of a transforming the EU into a more heterogeneous space of political and cultural norms.

Clearly, the geopolitical identity of V4 is not merely an academic issue, nor is it a solely a question of cooperation policies and practices. This is evident from the different ways in which V4 geopolitics can be interpreted and the rich scholarship that has pondered the V4's significance within the wider European context. From this literature emerges a diverse array of perspectives, not all of them overly positive. For example, despite the group's almost three decades of cooperation in areas such as energy, culture, education, environmental protection and the economy, recent framings of V4 cooperation paint a stark picture of the group's future, both in terms of East-West difference within the EU and divisions between V4 members themselves (Klus, 2015; Pakulski, 2016; Racz, 2014). Moreover, powerful narratives of Central European illiberalism have promoted a tendency to associate all V4 members with the nationalconservative agendas of Hungary and Poland.

We must remind ourselves that the visionaries behind the idea of Central European cooperation were striving to make their own imprint on Europe rather than simply appropriate pre-defined rules, values and ideas. The notion of Central Europe was recast by intellectuals such as Jenő Szücs, Czesław Milosz and Milan Kundera in order to signal a move from imagining Central Europe as a sphere of influence to constructing it as a partner in the broader integration of Europe (Trencsényi, 2017). Vaclav Havel saw in Visegrád cooperation a wider contribution to developing Europe based on "the special ethos created by our freshly won freedom." However, it is undeniable that while guaranteeing democratic freedoms, post-1989 reforms also promoted a sense of core-periphery dependency and economic if not political domination by powerful western European states, Germany in particular (Dutka, 2016; Vliegenthart, 2010).

The illiberal turn can be thus partly explained in terms of realist geopolitical contestations of pan-European conformity, for example with regards to accommodating asylum seekers (Szalai, Csornai, \& Garai, 2017). Shifts in the V4's geopolitical orientations can also be interpreted as a reflection of post-Millennial contexts of political and economic crisis and the renewed salience of national identity politics within the context of European integration. Indeed, some observers see disruptive transformation as the principal explanation for Central and East European illiberalism. Krastev and Holmes (2019) argue, for example, that liberalism was a 'God that failed Eastern Europe', creating a broad sense of discontent and disillusionment 
that has fed a nativist backlash against Europeanization. Krastev and Holmes (2018) also suggest that the illiberal turn is in large part a 'humiliation-driven' repudiation of western standards. As Buzogány and Varga (2018) remind us, the conflation of liberal democratic values with capitalism and neo-liberal ideology acted as a catalyst for eurocritical shifts. Hence, suggestions have been ventured that V4 cooperation could be evolving into an alternative model of bottom-up Europeanization (Mogildea, 2018) and/or a new form of regional cohesion based on social conservatism and national interests (Kazharski, 2018).

Consequently, the 'illiberal turn' is anything but a straightforward issue of 'East-West difference' but rather the result of a complex interplay of factors. Moreover, populism and illiberalism have become general features of national politics within the EU, albeit to different extents, forming an anti-EU mainstream of sorts. 'Illiberal Eastness' is itself a geopolitical imaginary based on normative notions of Europeanization and stereotyped thinking, both of which ignore the contested nature of European construction. I therefore suggest that these questions can be approached through an ontological security perspective that links instrumental, ideological and identity-driven rationales which condition the creation of European political and security community (see Della Sala, 2016; Mitzen, 2006; Kinnvall \& Mitzen, 2017). Ontological security involves, among other things, a constant process of creating and recreating narratives of political community, including a national sense of Self. A major aspect in this context is the emphasis of values, narratives of national purpose and historical memories that stabilise the identity of a given country (Rumelili, 2018). In the case of Central European EU member states, identity questions are accentuated by processes of what I suggest can be described as a specific kind of 'nation-making', that is: the forging of a sense of positionality and purpose within an evolving European political community.

As discussion will indicate, the political shifts of Visegrád 4 states are not simply opportunistic reactions to the EU's shortcomings, they reflect political struggles to achieve a new 'strategic positionality' in uncertain times (see Richardson, 2018). In terms of V4 subregional cooperation, illiberalism can be interpreted as conditioned by EU positionalities, domestic concerns and political pressures against common V4 positions. In the following, discussion will first centre on the theoretical background and assumptions relating to the concept of ontological security relevant to this study. Analysis will then focus on the nexus between ontological security and positionalities reflected in conservative agendas, value orientations and pragmatic national interests. I will particularly focus on Hungarian national conservative appropriations of V4 cooperation as exemplifying the emergence, ideological 
rationales but also the tensions involved in the illiberal turn. In concluding, I argue that the V4's geopolitical flexibility could ultimately be threatened by illiberalism should the nation-building projects of Hungary and Poland vie for hegemony in defining the V4's Central European identity. 'Alternative' European values might provide a basis for greater V4 relevance but only to the extent that regional coordination, economic modernisation, territorial development and a lobbying of influence within the EU 27 are not jeopardised.

\section{Connecting Critical Geopolitics to Ontological Security}

Particularly salient for this discussion is the close link between ontological security, Europeanization and strategies of national positionality within the wider European context. In terms of (geo)political psychology, ontological security is a question of identity and the stability of ideas, values and points of common reference that create a sense of group belonging (Mitzen, 2006). The salience of the concept is evidenced by attempts to achieve "epistemic coherence in times of uncertainty" (Natorski, 2015, p. 4). Along similar lines Gerard Toal (2017:39) argues that "every state or aspiring state has a geopolitical culture (...) defined as its prevailing sense of identity, place and mission in the world.” The histories of Central European geopolitical thinking are rich and exhibit a conceptual continuity that has withstood turbulent times. In this way, Hungarian Turanism (see Balogh, 2020), Polish Jagellonianism (Ištok, Kozárová, \& Polačková, 2018) or Czech anti-geopolitical traditions (Drulák, 2006; Kazharski, 2019) continue to be mobilised in contemporary contexts. Nevertheless, these geopolitical ideas are neither hegemonic nor immutable. Ontological security also implies a need for adaptive change in order to address new challenges. Favouring continuity in situations of deep uncertainty or in the exclusion of alternative policy options carries a risk of misrecognition and misleading understandings of reality (Chernobrov, 2016). Richardson (2018) suggests that ideological positions as well as pragmatic and dynamic elements of geopolitical thinking need consideration in order to reflect shifting geo-economic realities and domestic concerns. Following Richardson, a nuanced perspective would also consider the inherently fluid nature of subregional cooperation and geopolitical imaginaries which, despite their historical anchorings, represent national attempts at achieving 'strategic positionality' in uncertain times.

Ontological security, for example, can be threatened by rapid political change and can be manipulated via threat scenarios which target specific communities and organisations. Thus, the threat potential of perceived negative difference between peoples, cultures and states is a constant concern (Rumelili, 2014). More than merely an abstract concept, ontological security 
is observable in concrete situations such as in the self-referential nature of securitisation and threat perception (Palonen, 2018). This is, for example, clearly evident in the 'Hungarikum' of the moral panic button through which government-controlled media in Hungary instil popular fear of the migrant Other, conflating existential threats with cultural anxieties about Hungary's future within the EU (Barlai \& Sik, 2017).

Europeanization is a powerful geopolitical imaginary according to which economic integration, socio-political interaction and socialisation are creating a common space based on a recognition of mutual interdependence. However, interpretations of the rationales, mechanisms and impact of Europeanization differ considerably. An ontological security perspective can be used to challenge understandings of Europeanization based on convergence between European states and societies and a shared transcendence of past traumas. On this view, Europeanization cannot be reduced to policy adaptation and conformity, nor can it be comprehended as unidirectional political socialisation - it is a process that is conditioned by socio-spatial imbalances, centre-periphery tensions (Buhari-Gulmez \& Rumford, 2015; Celata $\&$ Coletti, 2019) as well as national experience and narratives that link national pasts with European futures (Della Sala, 2018). These narratives are instrumental in interpreting the social world, which includes geopolitical environments, and as such aim at stabilising the biographical continuity of political communities. Such narratives can also involve a break with uncomfortable pasts (Della Sala, 2016) and as well reinterpretations of history that serve to consolidate a sense of national identity. For example, Bahar Rumelili (2018) argues that temporal othering with regard to historical memory - i.e. the central role of Stunde Null moments of national re-birth with regard to overcoming traumatic events and legacies of fascism, communism, war, etc. - was central to the constitution of the EU's identity as a political community.

Central Europe's process of accession to and membership in the EU has involved finding a place within an already established political community. Central European states have very different national pasts from the founding member states and, as Mälksoo (2010) states, they have also challenged the imposition of EU-European identities based on western interpretations of post-World War II experience. Common to all post-socialist states, at least in general terms, is the experience of societal transformation and the socially polarizing effects of economic reform, particularly of neo-liberal reforms necessitated by European integration. Another issue is certainly the narration of an 'East-West divide' within Europe and the European Union. This 
divide has been conceptualised in rather different ways: as a reflection of structural and socioeconomic asymmetries, as historical and cultural difference and as an expression of coreperiphery relations between old and new member states (Ágh, 2010; Kuus, 2007; Müller, 2014; Zarycki, 2014). Structural and socio-economic data indeed substantiate the existence of development and income gaps as well as the argument that the EU is dominated by a more-orless permanent hegemony of strong states to which Germany, France and other members belong (Della Sala, 2018). Post-1989 transformation was disruptive to the societies of V4 states in many senses; full de jure sovereignty was regained, and state socialist institutions quickly dismantled, but the construction of new democratic societies proceeded fitfully. Ultimately, with the crisis of 2008/9 and its aftermath, belief in the EU's ability to provide greater prosperity suffered (Cichocki, 2017). As the geopolitical imaginary of Europeanization has faltered, EastWest normative gaps, crises of national purpose and social well-being have been met by more nationally oriented policy choices in tandem with culturalist and 'illiberal' narratives that influenced popular attitudes towards mainstream EU values.

East-West 'difference' as frequently narrated in the media is reflected in the suggestion that Central European member states are questioning their commitments to the EU. However, this simplified narrative obscures the fact that through the platform of Visegrád cooperation its members are striving to maintain identifiable political roles with regard the European Union. Appropriating the ontological security approach, I suggest that Visegrád cooperation is closely linked to projects of nation-making in the very specific sense of defining political roles (positionality) within the context of European integration. As will be discussed below, this is also evidenced by the fact that the Visegrád Group operates as a geopolitical space that provides an overarching narrative of European integration while allowing for the adjustable alignment of domestic agendas and concerns.

\section{VISEGRÁD 4 AND (GEO)POLITICS OF EUROPOSITIONALITY}

Understanding Europeanization through the prism of national positionalities directs our attention to processes by which narratives of national purpose within the EU are generated, particularly under conditions of disruptive change and geopolitical uncertainty. Moreover, positionality is used here to suggest a means of adjusting domestic political agendas, including national conservative ones, to acting politically as EU member states. It is a process of mutual conditioning and contestation that helps explains variation within Europe - for example, 
between that which is considered 'East' and 'West'. The Visegrád Group's geopolitical orientations have therefore reflected historical experiences of its members as well as vicissitudes of accession to and membership in the European Union. Heralded as an example of post-Cold War political and economic integration, the V4 maintain an official identity as a platform for dialogue and cooperation within Central Europe and this is expressed by a number of institutions and platforms that maintain the cooperation agenda (Cabada, 2018).

Irrespective of the V4's shortcomings, the group's sustainability and significance is arguably due to the fact that in Central Europe nation-building represents unfinished business - it is a process that was curtailed by war and its geopolitical aftermath and that has often coincided uncomfortably with the simultaneous project of European integration. At one general level the Visegrád Group is founded on a sense of identity that derives from 'betweenness' and geographical, political and historical liminality (Lebow, Mazurek, \& Wawrzyniak, 2019). There is arguably a shared 'sense of tragedy', described by Milan Kundera (1984) as a forced separation from Western Europe and István Bibó (1946) as frustrated nation-building due to external interference and geopolitical circumstances. A further common experience, at least in general terms, is the 'condition of post-Communism' (Schöpflin 1993) in which the construction of liberal democracies has taken place in hierarchical political cultures unfamiliar with the agonistic workings of parliamentary systems. Under these circumstances, it is clear why Visegrád cooperation was conceptualised by visionary advocates such as Vaclav Havel as a means to develop a sense of common European values. In addition, the visionary idea of creating Europe as a joint project was (and remains) closely linked to a need to create stable conditions for national development and economic transformation (see Nagy \& Nagy, 2013; Pisciotta, 2016 and Varró, 2008). Examples of this were the facilitation of EU and NATO membership and the formation of the Central European Free Trade Area (CEFTA) in 1992. Above and beyond this, V4 cooperation has been instrumental in promoting the response capacities of its members to external challenges (Törő, Butler, \& Grúber, 2014). It also provides leverage to its members who face obstacles in negotiating influence within the EU against the political and economic weight of the larger member states.

\section{The Illiberal Turn: Disruption, Populism and Conservative Nation-Making}

Central to this discussion is the context of change brought about by post-Millennial political and social disruption. In the last few years the Visegrád Four has gained notoriety as a centre of EU contestation and the media have characterised the group as political front against, for 
example, the EU's attempts to manage its refugee dilemma. While by no means underplaying the dangers of populism and creeping autocracy, I suggest that the so-called illiberal turn reflects a strategy of linking domestic and European-level concerns and a need to stabilise 'national selves' in the post-Millennial context of economic crisis, insecurity, neo-liberalism, austerity and the near-demise of a sense of EU-wide solidarity. As Algan et al. (2017) document, crisis-driven economic insecurity has been a major driver of populism in Europe. We can thus trace a chronological progression from the political strengthening of populistnationalist parties in the early 2000s, financial crisis of 2008-2009, the 2010 nationalconservative electoral victory in Hungary, a similar Polish political shift in 2015 and, in the same year, the dramatised spectacle of refugees seeking safety in the EU. The turn was precipitated in large part by the confluence of several factors, including the rise of domestic populism and nationalist identity politics. This favoured the emergence of new and more conservative stabilizing narratives of positionality that have partly incorporated right-wing culturalist and anti-elitist rhetoric (Havlík \& Stojarová, 2018).

Kazharski (2018) suggests that events such as the refugee issues not only supported radicalism in Visegrád Four countries but revealed already existing normative divides in terms of values and political culture. At one level, this divide reflects more general trends in Europe - nationalist populism has achieved a degree of common-sense status through invoking threat scenarios, Euroscepticism, everyday insecurity and islamophobia (Scott, 2017). Krasteva (2017) argues that, in addition to multiple crises, populist Euroscepticism of Central and Eastern Europe has been fuelled by the inability of national elites to communicate EU integration as a meaningful political project as well as by the inability of Brussels to convincingly connect the conditionalities of EU integration with a sense of democratic development and ownership. As Fenko, Požgan and Lovec (2019) indicate, overoptimistic popular expectations of EU membership, encouraged by a lack of measured debate on the costs and benefits involved, gave way to disillusion and a loss of faith in the utility of European integration. For example, according to some assessments the EU's institutional responses to the financial and refugee crisis have led to popular disaffection. Among lower-income Czech citizens, for example, EU membership was not perceived as helping local economies while the refugee crisis increased Euroscepticism among the Czech middle-class (McEnchroe, 2019).

To varying degrees, the anti-EU and anti-elitist backlash that ensued has manifested itself in identitary re-borderings and a discursive reassertion of national sovereignty. Austerity and neoliberal policies have been disruptive to the transformation trajectories of Central Europe 
states (see Wilkin, 2016). It is not just a case of disappointment with the results of membership benefits; neoliberalism in particular has been interpreted as an anti-statist political strategy foisted upon new member states with which to subject control of national societies and economies to globally operating market actors. Rather than using 'zombie' State Socialism (Chelcea \& Druţă, 2016) as the template for othering, a common denominator of illiberal populism in Central Europe is a questioning of many of the basic premises of European Union, particularly more cosmopolitan ideas of shared European citizenship and cultural tolerance. Playing on a politics of national alienation, illiberalism has sought to change the rules by which questions of migration, citizenship, and ultimately mobility are discussed and dealt with politically. Nevertheless, as dramatic as it appears, the illiberal turn marks only a partial transformation of the group's geopolitical identity. There is no question that the visionary Europeanism shared by Central European elites remains part of the historical identity of the Visegrád Group as it references epochal shifts in Europe's interstate relations and democratic development while signalling the transformative political role of Central Europe. It is a positive story of national rebirth and a popular desire for freedom that has promoted transcendence of the state socialist legacy. In practical terms, however, this intellectual vision has receded from view, taking a back seat to the problematic task of promoting national interests within a European context. Moreover, European integration has revealed historical divisions between the four countries, for example in the form of ethnopolitical tensions between Hungary and Slovakia. While such these tensions potentially threaten the viability of V4 cooperation, Europeanist momentum has been sustained through developing European agendas in areas such as defence policy, energy security and efficiency, food security, water, Cohesion Policy and the EU's Eastern Partnership. Moreover, Visegrád cooperation has also involved lobbying in EU agencies and representations for Central Europe (Törő, Butler, \& Grúber, 2014).

The maintenance of the Visegrád Group's positionality between the level of European politics, different member interests and domestic pressures has required balancing EU-critical positions with sustained commitments to developing the EU as a functioning political community. Common Visegrád positionalities contain value-based and pragmatic elements, as is evidenced by the joint statement issued at the occasion of the Rome Declaration of March 2, 2017. The statement reiterates the group's rejection of centralised relocation of refugees and multi-speed Europe policies, but also voices redoubled support for EU Cohesion Policy (Gotev, 2017). One common message that emerges from the V4 stance on refugees is that local sensibilities and cultures need to be taken into consideration and indeed, there appears to be 
scant popular support in any of the four countries for admitting refugees (Zachová et al., 2018). However, far from representing a concerted shift in orientation, the Group's move towards conservatism, nationalism and culturalist understandings of Europe is highly nuanced and reflects specific national contexts. Furthermore, Czech and Slovak commitments to illiberal ideas have been much less pronounced and sustained than those of Hungary and Poland.

\section{Hungarian and Polish Positionalities}

In the case of Hungary and Poland, the illiberal turn reveals a very strong ideological bent that is closely tied to conservative re-framings of national identity within the European context. Hungarian and Polish versions of national-conservative nation-building are premised on a specific set of beliefs with regard to history and the political consequences that can be drawn from past experience. For example, Hungary's 2011 Fundamental Law, or Constitution, outlines a conservative understanding of the country's place in Europe. The new constitution emphasises the 'role of Christianity in preserving nationhood' (Republic of Hungary, 2011), and also conveys a clear ethnopolitical message directed at Hungarian minorities living in the Carpathian Basin. Furthermore, according to the Hungarian government's strategic foreign relations strategy, adopted in 2014, national identity is: '(...) shaped by idiosyncratic national, Central European and European values, interests and experience.' (Hungarian Ministry of Foreign Affairs, 2014). Moreover, the historical memory of once large nations features prominently in the evocation of Hungarian Kingdom - and the Carpathian Basin that it encompassed, and the Polish-Lithuanian Rzeczpospolita as a basis for new cooperation and the desires of Hungary and Poland to be recognised as 'middle powers' (Hajdú, 2019; Nyyssönen, 2018). In both cases the emergence of powerful nation-building discourses reflects a desire, particularly on the part of conservatives, for a more positive understanding of national pasts as well as present and future positionality within the European Union. These narratives are aimed at re-framing a national sense of pride and purpose, extolling the contribution of the nation to the greater European good and civilisational development. Significantly, these narratives are also culturalist in Vertovec's (2011) sense of the term, involving a conception of (national) culture as reified, static, and largely homogeneous.

The conservative push involves a directed campaign of temporal othering in which the victory of national-conservative forces signifies a genuine end to transition and the reestablishment of true and legitimate national sovereignty. For example, according to this narrative, while the socialist system as such was swept aside in 1989, the post-socialist 
experience was an incomplete process of national becoming until the grand electoral victory of FIDESZ was achieved in 2010. ${ }^{1}$ These expressions of cultural politics are part of a nationalconservative project of nation-building, ${ }^{2}$ in which Hungary is (finally) realizing its role as a 'strong and proud European nation', following its own political destiny but within the context of European cooperation. ${ }^{3}$

Similarly to the Polish government, Hungary has injected its national message of moral rebirth into Central European cooperation with the highly ambitious goal of changing the trajectory of European Union towards a nationally constituted one. In a visit to Kraków, Poland in December 2016, Hungary's Prime Minister announced that "Central Europe is experiencing a renaissance and is growing and developing continuously and dynamically". Similarly, the Future of Europe Conference organised in Budapest in May 2018 was framed by several provocative questions that left little doubt as to the central ideological message conveyed by the Hungarian V4 presidency: ${ }^{4}$

Is the war for Europe's body and soul a winnable one? Can we defeat censorship, the shaming of those who think differently, the increasing cultural self-hatred in Europe? (...) Will Europe become the new melting pot? Shall we, out of cultural guilt or simple calculation, sacrifice Christianity, freedom and our way of life? Or should we retreat to our fortress, defend ourselves and strengthen our values and cohesion within? Is the creation of the New European Man realistic through migration?

Prime Minister Viktor Orbán has portrayed Hungary and its Central European neighbours as a centre of new European ideas that more closely adhere to public sentiment. On this view, Visegrád members are not mere emulators of the West, but are innovators and makers of Europe according to notions of a nationally defined Christian Europe - and against Brussel's 'political correctness' (Butler, 2017; Szarka, 2017). Hungarian and Polish commitments to valueorientations have in fact emerged as a broader geopolitical strategy to stabilise the national conservative narrative, for example through a rejection by the most conservative political

\footnotetext{
${ }^{1}$ Lovas, I.: Húsz éve erre vártunk. Magyar Nemzet (4 November 2010). The central message of this opinion piece is that Hungary has waited 20 years for a truly national government, a government that represents national interests. ${ }^{2}$ The Fidesz official website announces in a June 2014 blog that 'a new era of nation-building is possible' (A nemzetépítés új korszaka jöhet), available at http://www.fidesz.hu/hirek/2014-06-09/a-nemzetepites-uj-korszakajohet/ (accessed 12 June 2017).

${ }_{3}$ As reflected in a poster campaign that advertises Hungary as a 'strong and proud European country', http://putitright.eu/?p=2523 (accessed 12 June 2017).

4 The text is taken from the following conference website: The Future of Europe”/„Európa Jövője”, http://europajovojev4.eu/en/\#koszonto (accessed 10 January 2020).
} 
groupings of liberalism's individualist character and as a force that has undermined society and state in economic, political and social terms (Buzogány, 2017). The consolidation of Hungary's activist positionality is furthermore evidenced by the highly visible exploitation of refugee 'threat' as part of a broader geopolitical ambition to push for a more conservative turn within the EU as a whole. And indeed, the forceful nature of the Hungarian government's arguments against accommodating refugees is based on a strategy of invoking the inviolability of national borders and exaggerating threats to national cohesion, identity and sovereignty (Scott, 2020).

Poland's national conservative government has also projected national identity politics, as well as its Catholic religious identity, onto V4 cooperation. Since 2015, the Polish government has sought to strengthen a sense of V4 identity based on national traditions and to fortify a common position on European reform. Similarly to Hungarian proclamations, the Polish conservative vision of Europe includes a moral Union explicitly based on Christian values. According to the Polish Ministry of Foreign Affairs $(2017,21)$ :

"Since the European Union is not only a Union of interests, but also a Union of values, the Republic will support its activities to respect democratic freedoms and human rights. Referring to the most glorious traditions of the Polish-Lithuanian Commonwealth, we will attach great importance to freedom of thought and conscience and interreligious dialogue as a way of building peaceful relations between religious communities, preventing extremism, intolerance and terrorism. Actions on this should also be seen in the context of improving the position of Christians, the most persecuted religious community in the world."

These ideas informed the priorities of the Polish Visegrád Presidency (2016-2017) which included strengthening the voice of the V4 within the EU, security and stability, transportation networks, commitment to more regional dialogue, and, as mentioned above, emphasizing common values as a means to strengthen V4 identity. Moreover, in the opinion of the present Polish administration, the main threat to the sustainability and stability of the European Union is the prospect of transforming it into a bureaucratic project with little subject to democratic (i.e. national parliamentary) control. A further deepening of integration is interpreted as undermining the sovereignty of Member States. Nevertheless, despite sharing an ideological stake in political illiberalism, Polish national conservatives maintain a certain distance from their Hungarian partners due to ambitions of regional influence that are enabled by Europeanlevel policy processes. Furthermore, Poland's antagonism towards Russia as a security threat 
and as a revisionist power cannot be easily reconciled with Orban's much more accommodating position (Zając, 2018).

\section{The Czech Republic and Slovakia: A Pragmatic Middle Ground?}

Populism and conservative attitudes are embedded in the post-1989 political cultures of the Czech Republic and Slovakia. However, in these two countries illiberalism does not manifest itself as a clear geopolitical strategy directed towards the European Union; it lacks the ideological drive that stems from Hungarian and Polish nation-building projects. Slovakian national populists are illiberal in substance, for example in terms of governance, but as yet do not have a national development vision that could be injected into the V4 context (Havlík, 2019). Czech populists also lack a strong nationalist narrative or ideological foundation (Hanley \& Vachudová, 2018) and, as Havlík (2019) argues, are instead rather technocratic in approach. Nevertheless, V4 unity was instrumental in politically bolstering decisions to reject the EU's solidarity quotas for admitting refugees - this was indeed based on a shared fear of renewed disruption and, as a result, social tensions and financial burdens (Zachová et al., 2018).

The lack of an ideological nation-building agenda is evidenced by comments of Slovak State Secretary Korčok, who has stated that the role of Slovakia within the V4 (and EU more generally) is to promote a politics of compromise as well as contribute to economic competitiveness (Gabrizová, 2018). Korčok has also suggested that “... Slovakia is a voice of rationality in its region in the sense that Slovakia communicates the importance of preserving and even the deepening of European integration" (ibid). Of the four Visegrád states, Slovakia is the only one that is part of the Eurozone and the only country that has targeted carbon neutrality by 2050 . As Geist (2017) suggests, Slovakia would rather actively participate in 'Core Europe' than in a V4 which is clearly instrumentalised for domestic political objectives by its members. The election of Zuzana Čaputová as Slovakian President in 2019 confirmed the country's more marked Europeanist stance. Nevertheless, while President Čaputová supports pan-European management of migration she has also advised that the EU recognise and respect the anxieties and fears of the CE countries who are unfamiliar with and fearful of mass migration and multiculturalism (Kaufmann, 2019).

One of the main divergences between the V4 members are the intergovernmental options for European integration favoured by Hungary and Poland. The reasons for this difference are selfevident: as mid-size regional actors, Hungary and Poland are much more interested in a greater degree of national freedom of movement within an EU of sovereign nation-states. In contrast, 
the Czech Republic and Slovakia prefer federalist arrangements in order to maximise their political voice within the EU. Slovakia, a small country with five million inhabitants, advocates the communitarian model as a means to balance different regional interests. For Slovak elites, avoiding marginalisation within an East-West division of Europe is a long-standing constant geopolitical narrative that partly explains, broadly speaking, a more pro-European positionality, particularly within the disruptive context of fragmentation within the European Union (Kazharski, 2019).

With its assumption of the V4 presidency in 2019 the Czech government advocated "a rational, pragmatic and constructive approach to the challenges and problems, which our countries and the whole Europe are facing." (Ministry of Foreign Affairs of the Czech Republic 2019). However, it is also true that Czech governments have at times been among the least enthusiastic supporters of regional cooperation, particularly under Eurosceptic President Vaclav Klaus (2003-2013). The priorities defined by Czech V4 presidencies are informed first and foremost by development concerns: economic growth, innovation, support to lagging regions, communication networks and a broadening of cooperation options within and beyond the EU.

While Hungary and Poland accentuate normative divides as a Central European strength, the Czech Republic and Slovakia are much more circumspect. Szomolányi and Gál (2016) have, for example, identified a gap between the populist rhetoric of the ruling Slovak political class, and their political practices which have been much more in line with EU policies. Similarly, Czech and Slovak political elites have refrained from criticising Hungary and Poland openly, however, this solidarity ends when concrete decisions regarding the thorny issue of political sanctions against Poland are taken. For example, the Czech Republic and Slovakia did not oppose the 2018 suspension of Poland's National Judiciary Council from the ENCJ (European Network of Councils of the Judiciary (Ochman, Zbytniewska, \& Plevák, 2018). At the same time, Visegrád countries are united in the promotion of EU enlargement and against reforms of membership negotiation rules. They also support the maintenance of a robust Cohesion Policy targeted at socio-economic convergence while negotiating and managing sustainability initiatives such as Green Europe that will affect energy-intensive sectors.

Vít Dostál (2019), Executive Director of the Prague-based Association of International Affairs, has argued that the 
"Hungarisation' of the Visegrád Group is harmful to the rest of Central Europe, and the 'East-West divide' rhetoric, on which Viktor Orbán relies to present himself as the saviour of a new Europe, is a disaster for Slovakia - the only Eurozone member of the Central European bloc".

Hungarisation has created tensions in other ways as well. Slovakian Justice Minister Mária Kolíková and Foreign Minister Ivan Korčok forcefully rejected Hungary's suggestions of mainstreaming a more conservative model of the rule of law, adding that there was little sense in creating a parallel rule of law contradicting the principles set by the EU (quoted by Slovakian Spectator, 2020). Minister Kolíková, who expressed 'shock' at the Hungarian initiative, also railed against Hungarian and Polish attempts to appropriate the 'V4 brand' for their own political agendas (Gabrizová, 2020).

\section{CONCLUSIONS}

Two questions guided this study: the extent to which the imaginary of illiberal Eastness reflects the actual positionalities of V4 member states and reasons for V4 resilience as a geopolitical strategy despite a questioning of its overall political impact. Returning to the ontological security perspective elaborated earlier, the illiberal turn in V4 geopolitics can be characterised as a blend of pragmatic and identity-based agendas through which nation-building trajectories and the European positionality of its members have been enhanced. V4 cooperation derives strength from bundling together common elements of Central European national experience while remaining open for the individual articulation of regional and European positionalities. This cooperation also addresses popular insecurities in the face of disruption and change, both real and imagined, that economic crisis and refugee controversies laid bare. The above suggests that V4 cooperation has allowed for a certain solidarity during a period of insecurity in national actorness, it has allowed its members to jointly manage the legacy of marginality by serving as a vehicle for negotiating a place and role within Europe (Neuman, 2017). This has been possible because the group operates without the need for consensus (Boros, 2017). According to Slovak State Secretary for European Affairs Ivan Korčok: “... the V4 works by forming ad hoc positions to ad hoc issues. If we agree, we are together, if we do not agree, we are not together without breaking up" (Gabrizová, 2018). As Krastev (2017) points out, what Brussels describes as a lack of solidarity with regard to the acceptance and treatment of refugees is actually a clash of national, ethnic, and religious solidarities and thus moral and legal obligations. In this way, 
the illiberal turn is largely an issue of exploiting normative divides as a strategy of positionality that, to an extent, has strengthened the hand of V4 states. However, the extent to which this is put into practice differs considerably.

Celata and Coletti (2018) remind us that imposing an overarching and ultimately Westcentric narrative of the EU's historical emergence could create a backlash de-Europeanization. V4 geopolitics indicate that, despite the illiberal turn and its baleful consequences, East-West divisions are overstated in terms of civilisational and deep cultural difference but that they exist as historical contingencies and collective understandings of national positionality that influence interpretations of the European Union and its sense of purpose. Ontological security indeed implies a need for adaptability and interpretative openness (see Vieira, 2016) - only in this way has it been possible to reconcile the nationalist agendas of Hungary and Poland with the more measured 'Europragmatism' of the Czech Republic and Slovakia. Nevertheless, pragmatic positionality is now sorely tested by the divergence of national positionalities with regard to the European Union. Indeed, Hungary's and Poland's projects of national-conservative autocracy could have a long-term negative effect. Novotná and Stuchlíková (2017) criticise that V4 cooperation has been used to shield its members from critical scrutiny (in this regard) rather than generate constructive proposals for EU reform. For example, strengthening local and regional elements of cross-border cooperation would indeed be of essential importance in (re)creating economic, social and political networks and addressing environmental and many other border-transcending problems that the V4 states face.

Predicting the future development of illiberalism and autocracy within the EU in general and Central Europe in particular is fraught with countless unknowns. However, despite the troubling backdrop of illiberalism, European integration should be interpreted as an agonistic and contested process that nevertheless offers space for a pluralistic understanding of political community. Hence, as Maria Mälksoo (2010) has suggested, a more heterocentric understanding of Europeanization could be the point of departure for moving towards a common European future.

\section{Acknowledgement}

Research for this publication has been supported by the Hungarian National Research, Development and Innovation Office - NKFIH grant 134903 (Geopolitical Processes and Imaginaries in Central Europe: States, Borders, Integration and Regional Development). 


\section{REFERENCES}

Ágh, A. (2019). The Neoliberal Hybrid in East-Central Europe. The 'Treason of Intellectuals' and its Current Re-assessment. Politics in Central Europe, 15, 355-381.

Algan, Y., Guriev, S., Papaionnou, E., \& Passari E. (2017). The European Trust Crisis and the Rise of Populism. Brookings Papers on Economic Activity, 309-382.

Balogh, P. (2020). Clashing Geopolitical Self-Images? The Strange Co-Existence of Christian Bulwark and Eurasianism (Turanism) in Hungary. Eurasian geography and economics. Doi: $10.1080 / 15387216.2020 .1779772$

Fenko, A. B., Požgan, J., \& Lovec, M. (2019). Crises of the EU and the rise of populism and Euroscepticism in CEE. In Lovec, M. (Ed.), Populism and attitudes towards the EU in Central Europe (pp. 41-70). Ljubljana: University Faculty of Social Sciences.

Barlai, M., \& Sik, E. (2017). A Hungarian trademark (a "Hungarikum"): The moral panic button. In Barlai, M., Griessler, C., Fähnrich, B., \& Rhomberg, M. (Eds.), The Migrant Crisis: European Perspectives and National discourses (pp. 147-168). Zürich: LIT Verlag.

Bibó, I. (1946). A kelet-európai kisállamok nyomorúsága [The Misery of Eastern European Small States]. Budapest: Szikra Irodalmi és Lapkiadó Vállalat.

Boros, T. (2016). Hungary: The Country of the Pro-European People and a Eurosceptic Government. Truth About Lies on Europe blog, http://trulies-europe.de/?p=374 (Accessed 08 January 2020).

Boros, T. (2017). Hungary and the Visegrad Four. In Skrzypek, A., \& Skóra, M. (Eds.), The Future of the Visegrad Group (pp. 13-17).

Buckley, N. \& Foy, H. (2016). Visegrad Four: the EU's Eastern Critics. Financial Times, 29 August 2016.

Buhari-Gulmez, D., \& Rumford, C. (2016). Towards a ("thick", "thin", or "parallel") European Society? Understanding the Dynamics of European Multiplicity. Innovation: The European Journal of Social Science Research, 29, 41-55, DOI:10.1080/ 13511610.2015 .1055457

Bunikowski, D. (2018). The Constitutional Crisis in Poland, Schmittian Questions and Kaczyński's Political and Legal Philosophy. Journal of Contemporary European Studies, 26, 285-307. DOI:10.1080/14782804.2018.1498771

Butler, E. (2017). The 'in Defense of National Identity' Argument: Comparing the UK and Hungarian Referendums of 2016. Europe Now, 2017(4), 01 Feb.

Buzogány, A. \& Varga, M. (2018). The Ideational Foundations of the Illiberal Backlash in Central and Eastern Europe: the Case of Hungary. Review of International Political Economy, 25, 811-828. DOI:10.1080/09692290.2018.1543718

Cabada, L. (2018). The Visegrad Cooperation in the Context of Other Central European Cooperation Formats. Politics in Central Europe, 14, 165-179.

Calhoun, C. (2007). Nations Matter: Culture, History and the Cosmopolitan Dream. London: Routledge.

Celata, F., \& Coletti, R. (2019). Borderscapes of External Europeanization in the Mediterranean Neighbourhood. European Urban and Regional Studies, 26, 9-21. https://doi.org/10.1177/0969776417717309

Chelcea, L., \& Druţă, O. (2016). Zombie Socialism and the Rise of Neoliberalism in Postsocialist Central and Eastern Europe. Eurasian Geography and Economics, 57, 521-544. DOI: $10.1080 / 15387216.2016 .1266273$

Chernobrov, D. (2016). Ontological Security and Public (Mis)recognition of International Crises: Uncertainty, Political Imagining, and the Self. Political Psychology, 37, 581-596. https://doi.org/10.1111/pops.12334 
Cichocki, P. (2017). Cosmopolitanism In The Face Of Populism - Contemporary Challenges On The Path Of European Identity Formation. Society Register, 1, 67-74. https://doi.org/10.14746/sr.2017.1.1.06

Della Sala, V. (2016). Europe's Odyssey?: Political mMth and the European Union. Nations and Nationalism, 22, 524- 541. https://doi.org/10.1111/nana.12159

Della Sala, V. (2018). Expert Comment. The EU and hegemony: The New Medievalism Revisited. Dialogue of Civilizations Research Institute, https://doc-research.org/wpcontent/uploads/2018/08/Della-Sala_Europe-and-hegemony_Download-file.pdf

Dostál, V. (2019). The 'Hungarization' of the Visegrad Group is harmful to the rest of Central Europe. https://www.amo.cz/en/the-hungarization-of-the-visegrad-group-is-harmful-tothe-rest-of-central-europe/

Drulák, P. (2006). Between Geopolitics and Anti-Geopolitics: Czech Political Thought. Geopolitics, 11, 420-438. https://doi.org/10.1080/14650040600767883

Dutka, J. (2016). Wpływ realizacji geopolitycznej koncepcji Międzymorza na bezpieczeństwo militarne Polski i Europy Wschodniej w XXI wieku [The impact of the geopolitical concept of Międzymorze on Poland's military security towards Eastern Europe in the 21st century]. Przeglad Geopolityczny, 16, 120-137.

Gabrizová, Z. (2018). Slovak state secretary: I am a strong advocate for a communitarian EU." Euractiv.sk, 1 March 2018. https://www.euractiv.com/section/future-eu/interview/slovakstate-secretary-i-am-a-strong-advocate-for-a-communitarian-eu/ (Accessed 2 February 2019).

Gabrizová, Z. (2020). Hungary misappropriated V4 brand, says Slovak justice minister. 5 November 2020. https://www.euractiv.com/section/politics/short_news/hungarymisappropriated-v4-brand-says-slovak-justice-minister/ (Accessed 03 May 2021).

Geist, R. (2017). Slovakia: Squaring the Visegrad Circle. In Skrzypek, A. \& Skóra, M. (Eds.) The Future of the Visegrad Group (pp. 23-28.) Brussels/Berlin: Foundation for European Progressive Studies and Das Progressive Zentrum.

Gotev, G. (2017). Visegrád Group Spells out its Vision of EU's Guture. Euractiv, 3 March 2017, https://www.euractiv.com/section/central-europe/news/visegrad-group-spells-outits-vision-of-eus-future/

Hajdú, Z. (2019). The Rebirth of the Concept of the Carpathian Basin in Hungarian Political Language after 1988. In Laine, J., Liikanen, I., \& Scott, J. W. (Eds.), Post-Cold War Borders. Reframing Political Space in Eastern Europe (pp. 207-227). Milton Park and New York: Routledge.

Hanley, S. \& Vachudova, M. A. (2018). Understanding the illiberal turn: democratic backsliding in the Czech Republic. East European Politics, 34, 276-296. DOI:10.1080/21599165.2018.1493457

Havlík, V. (2019). Technocratic Populism and Political Illiberalism in Central Europe. Problems of Post-Communism, 66, 369-384. DOI:10.1080/10758216.2019.1580590

Havlík, V., \& Storajová, V. (2018). Different Faces of Illiberal Party Politics in Central and Eastern Europe. In Solska, M., Bieber, F., \& Taleski, D. (Eds.), Illiberal and Authoritarian Tendencies in Central, Southeastern and Eastern Europe (pp. 313-342). Bern: Peter Lang.

Hungarian Ministry of Foreign Affairs, 'Hungary's External Relations Strategy. Unofficial Translation' (Budapest: Government of Hungary 2014), www.mfa.gov.hu/ NR/rdonlyres/3E8FA370-15B3.../080319_kulkapcs_strat_en.pdf(Accessed 12 June 2017).

Ištok, R., Kozárová, I., \& Polačková, A. (2018). The Intermarium as a Polish Geopolitical Concept in history and in the Present. Geopolitics. DOI:10.1080/ 14650045.2018 .1551206 
Jančošekovà, V. (2017). Regional Cooperation in Central and Eastern Europe and its Implications for the EU. European View, 16,: 231-238. https://doi.org/10.1007/s12290017-0460-8

Kaufmann, S. (2019). Le Monde 28/29 July 2019, Sylvie Kaufmann (interviewer) "La question migratoire est le problème de toute l' UE'.

Kazharski, A. (2018). The End of 'Central Europe'? The Rise of the Radical Right and the Contestation of Identities in Slovakia and the Visegrad Four. Geopolitics, (23)4, 754 780. DOI:10.1080/14650045.2017.1389720

Kazharski, A. (2019). Two kinds of small? The 'EU core' in Slovak and Czech geopolitical imagination. Journal of Contemporary European Studies, 27(4), 424-438. DOI:10.1080/14782804.2019.1598340

Klus, A. (2015). What Makes the Visegrad Group so Geopolitically Fragile? New Eastern Europe, 05 June. http://neweasterneurope.eu/old_site/articles-and-commentary/1617what-makes-the-visegrad-group-so-geopolitically-fragile

Kováts, E., \& Smejkalova, K. (2019). The EU's ongoing East-West divide: How the West's economic exploitation and moral arrogance fuel right-wing populism in East-Central Europe. International Politics and Society, 03.07.2019, https://www.ipsjournal.eu/regions/europe/article/show/the-eus-ongoing-east-west-divide-3575/

Krastev, I. (2017). After Europe. Philadelphia: University of Pennsylvania Press.

Krastev, I., \& Holmes, S. (2018). Explaining Eastern Europe: Imitation and Its Discontents. Journal of Democracy, 29(3), 17-28.

Krastev, I., \& Holmes, S. (2019). The Light that Failed. A Reckoning, London: Allen Lane.

Krasteva, A. (2017). If Borders Did Not Exist, Euroscepticism Would Have Invented Them Or, on Post-Communist Re/De/Re/Bordering in Bulgaria. Geopolitics, 25(3), 678-705. DOI:10.1080/14650045.2017.1398142

Kuus, M. (2007). Inscribing Europeanness, Erasing Eastness. In. Geopolitics Reframed. New Visions in Security. New York: Palgrave Macmillan.

Lebow, K., Mazurek, M., \& Wawrzyniak, J. (2019). Making Modern Social Science: The Global Imagination in East Central and Southeastern Europe after Versailles. Contemporary European History, 28 (2), 137-42.

Mitzen, J. (2006). Ontological Security in World Politics: State Identity and the Security Dilemma. European Journal of International Relations, 12, 341-370. DOI:10.1177/1354066106067346.

Kinnvall, C., \& Mitzen, J. (2017). An Introduction to the Special Issue: Ontological Securities in World Politics. Cooperation and Conflict, 52, 3-11. https://doi.org/10.1177/ 0010836716653162

McEnchroe, T. (2019). 15 Years after Accession - What is the Deal with Czech Euroscepticism? 01 May 2019, Radio CZ, https://www.radio.cz/en/section/panorama/ 15-years-after-accession-what-is-the-deal-with-czech-euroscepticism.

Mälksoo, M. (2010). The Politics of Becoming European: A Study of Polish and Baltic Postcold War Security Imaginaries. London: Routledge.

Ministry of Foreign Affairs of the Czech Republic 2019 Programme for the Czech Presidency of the Visegrad Group 2019/2020 "V 4 Reasonable Europe". https://www.mzv.cz/ file/3626458/Programme_CZ_V4_PRES_2019_2020_A.pdf (Accessed 20 February 2020).

Mogildea, M. (2018). The Visegrad Group: a regional integration model for advancing the Europeanization process in Central and Eastern Europe. Fellowship Policy Papers, Think Visegrad - V4 Think Tank Platform, https://think.visegradfund.org/fellowship-papers/

Nagy, E. \& Nagy G. (2013). The layers of dependence and the changing role of the state Conceptualising urban change in the East of Europe. Berlin: Humboldt-Universität http://www.rc21.org/conferences/berlin2013/RC21-Berlin-Papers-3/03_2_enagy_gnagy.pdf 
Natorski, M. (2015). Epistemic (Un)certainty in Times of Crisis: the Role of Coherence as a Social Convention in the European Neighbourhood Policy after the Arab Spring. European Journal of International Relations, 22, 646-670. https://doi.org/10.1177/1354066115599043

Neuman, M. (2017). The Visegrád Group as a Vehicle for Promoting National Interests in the European Union: The Case of the Czech Republic. Politics in Central Europe, 13(1), 55-67.

Nič, M. (2016). The Visegrád Group in the EU: 2016 as a Turning-Point? European View 15: 281-290. DOI:10.1007/s12290-016-0422-6

Novotná, T., \& Stuchlíková, Z. (2017). Czechia: From a V4-Enthusiast to a V4-Sceptic and Back Again. In Skrzypek, A., \& Skóra, M. (Eds.), The Future of the Visegrad Group (pp. 6-12). Foundation for European Progressive Studies and Das Progressive Zentrum, https://www.progressives-zentrum.org/wp-content/uploads/2018/03/The-Future-of-theVisegrad-Group_2018_ebook.pdf

Nyyssönen, H. (2018). The East is different, isn't it? - Poland and Hungary in search of prestige." Journal of Contemporary European Studies, 26(3), 258-269. DOI:10.1080/14782804.2018.1498772

Ochman, K., Zbytniewska, K., \& Plevák, O. (2018). The awkward squad: Czech-Polish cooperation on a different EU vision. Euractiv.cz and Euractiv.pl, 8 October 2018, https://www.euractiv.com/section/future-eu/news/the-awkward-squad-czech-polishcooperation-on-a-different-eu-vision/ (Accessed 2 February 2019).

Pakulski, J. (2016). Conclusions. In Pakulski, J. (Ed.), The Visegrad Countries in Crisis pp. 122-127). Warsaw: Collegium Civitas.

Palonen, E. (2018). Performing the Nation: the Janus-Faced Populist Foundations of Illiberalism in Hungary. Journal of Contemporary European Studies, 26, 308-321. https://doi.org/10.1080/14782804.2018.1498776

Pisciotta, B. (2016). The Center-Periphery Cleavage Revisited: East and Central Europe from

Postcommunism to Euroscepticism. Nationalism and Ethnic Politics, 22, 193-221.

Polish Ministry of Foreign Affairs (2017). Polish Foreign Policy Strategy, 2017-2021

Racz, A. (2014). The Visegrad Cooperation: Central Europe Divided Over Russia. L'Europe en Formation, 374, 61-76. DOI:10.3917/eufor.374.0061

Republic of Hungary (2011). Fundamental Law of Hungary, 25 April 2011. (English translation of consolidated version of 1 October 2013) available at http://www.kormany.hu/en/news/the-new-fundamental-law-of-hungary

Richardson, P. (2018). Geopolitical cultures, pragmatic patriotism, and Russia's disputed islands. Eurasian Geography and Economics, 59(1), 7-27. https://doi.org/10.1080/ 15387216.2017.1421474

Rumelili, B. (2014). Conflict Resolution and Ontological Security. Peace Anxieties. London: Routledge.

Rumelili, B. (2018). Breaking with Europe's pasts: memory, reconciliation, and ontological (In)security. European Security, 27(3), 280-295. https://doi.org/10.1080/09662839. 2018.1497979

Sarka, S. (2016). Ellen kell állni. A brüsszeli bürokrátak nem a nemzeti érdekeket képviselik [We must resist. Brussels bureaucrats do not represent national interests]. Magyar Demokrata, XXI/11 (16 March 2017), pp. 10-12.

Schmidt, A. (2016). Friends forever? The Role of the Visegrad Group and European Integration. Politics in Central Europe, 12(3), 113-140.

Schöpflin, G. (2000). Nations, Identity, Power. New York: New York University Press.

Scott, J. W. (2017). Extreme and Extremist Geographies: Commentary on the Revanchist Impulse and its Consequences for Everyday Bordering. Fennia - International Journal of Geography, 195, 102-105. 
Scott, J. W. (2020). Hungarian Border Politics as an Anti-politics of the European Union. Geopolitics, 25(3), 658-677, DOI:10.1080/14650045.2018.1548438

Slovakian Spectator (2020). Slovakia does not buy into defining an alternative to the rule of law with Hungary, https://spectator.sme.sk/c/22529378/slovakia-does-not-buy-intodefining-an-alternative-to-the-rule-of-law-with-hungary.html, access 10 April 2021

Smith, A. D. (2009). Ethno-symbolism and Nationalism: A Cultural Approach. Milton Park: Routledge.

Stormowska, M., \& Dufour, N. (2016). Poland: All Shades of EU Enthusiasm. In Pertusot, V. (Ed.), The European Union in the Fog: Building Bridges between National Perspectives on the European Union (pp. 169-175). Paris: Institut français des Relations Internationales.

Szalai, M., Csornai, Z., \& Garai, N. (2017). V4 Migration Policy: Conflicting Narratives and Interpretive Frameworks. In Morillas, P. (Ed.), Illiberal Democracies in the EU: the Visegrad Group and the Risk of Disintegration (pp. 19-30). Barcelona: Colección Monografías CEDOB.

Szomolányi, S., \& Gál, Zs. (2016). Slovakia's Elite: Between Populism and Compliance with EU Elites. In Pakulski, J. (Ed.), The Visegrad Countries in Crisis, Chapter 4, 67-86, Warsaw: Collegium Civitas.

Törő, C., Butler, E. \& Grúber, K. (2014). Visegrád: The Evolving Pattern of Coordination and Partnership After EU Enlargement." Europe-Asia Studies, 66, 364-393, DOI: 10.1080/09668136.2013.855392

Trencsényi, B. (2017). Central Europe. In Mishkova, D., \& B. Trencsényi, B. (Eds.): European Regions and Boundaries: A Conceptual History (pp. 166-187). New York: Berghahn.

Varró, K. (2008). Changing Narratives on EU Multi-level Space in a Globalizing Era: How Hungary as a National Space became Part of the Story. European Planning Studies, 16(7), 955-969. DOI:10.1080/09654310802163751

Vertovec, S. (2011). The Cultural Politics of Nation and Migration." Annual Review of Anthropology, 40, 241-256.

Vieira, M. (2016). Understanding Resilience in International Relations: The Non-Aligned Movement and Ontological Security. International Studies Review, 18, 290-311, https://doi.org/10.1093/isr/viw002

Vliegenthart, A. (2010). Bringing Dependency Back. In The Economic Crisis in Post-socialist Europe and the Continued Relevance of Dependent Development. Historical Social Research/Historische Sozialforschung, 35, 242-265. Retrieved from www.jstor.org/stable/20762458

Whittaker, N. (2018). The Island Race: Ontological Security and Critical Geopolitics in British Parliamentary Discourse. Geopolitics, 23, 954-985, DOI: 10.1080/14650045.2017.1390743

Wilkin, P. (2016). Hungary's Crisis of Democracy: The Road to Serfdom. Lanham: Lexington Books,

Zachová, A., Zgut, E., Zbytniewska, K., Strzałkowski, M, \& Gabrizova, Z. (2018). Visegrad Nations United Against Mandatory Relocation Quotas. Euractiv, 23 June 2018. https://www.euractiv.com/section/justice-home-affairs/news/visegrad-nations-unitedagainst-mandatory-relocation-quotas/

Zając, J. (2018). Polish Perception of Security Threats and Challenges of the 21 st Century. In Jankowski, B., \& Zima, A. (Eds.): France and Poland Facing the Evolution of the Environment (pp. 17-26). Études de l'IRSEM, 59.

Zarycki, T. (2014). Ideologies of Eastness in Central and Eastern Europe. Milton Park: Routledge. 